The National Library supplies copies of this article under licence from the Copyright Agency Limited (CAL). Further reproductions of this article can only be made under licence.

\title{
Framing the Female: Annie Carr as Colonial Model
}

\author{
Elizabeth Strain
}

$\mathrm{W}$

Thile there is ample evidence to suggest that the young adult novel was born out of the changed social climate of the 1960s, the notion of youthful readers caught between the happy innocence of childhood and the experience of adulthood was not a new one. The domesticnovel of the late nineteenth century served a similar function in blurring those boundaries between child and adult readers by assisting them to enter adulthood through narratives of romance, successful enterprise and virtue rewarded.

The Australian children's literature research collection in the State Library of Victoria contains many such texts whose main purpose was to enculturate young readers through narratives of romance, successful enterprise and virtue rewarded. Because it offers a version of our colonial past, Annie Carr: A Tale of Both Hemispheres is an interesting example.

As a novel of the 1890 s written to a female audience Annie Carr: A Tale of Both Hemispheres is inescapably enmeshed in the discourses of nationalism which constructed the meanings of Australian experience as a gendered cultural tradition. As a cultural product of this period this novel provides for a late twentieth century reader powerful testimony of the colonial ideologies of power, gender and class encoded within its constructions.

The mystery shrouding the production and publication of Annie Carr: A Tale of Both Hemispheres is appropriately in keeping with its narrative of mystery and disclosure. The anonymous author establishes literary authority by declaring on the title page authorship of a previous text Adventures in the South Pacific, an episodic narrative of colonising missionary endeavour in Pacific islands north east of Australia. Both texts were published in England by the Religious Tract Society whose connections with the Society for the Propagation of Christian Knowledge attested to the moral and Christian earnestness of its publications. While no publication date is cited, Annie Carr: A Tale of Both Hemispheres was awarded to a young female as a school prize in Australia in 1903 (Muir 1992, p.12).

As Stephens has observed: '... fiction must be regarded as a special site for ideological effect, with a potentially powerful capacity for shaping audience attitudes' $(1992$, p.9). The writing of the young female as cultural sign in a fiction written to and read by a youthful audience always possesses powerful socialising potential and Annie Carr: A Tale of Both Hemispheres is no exception. As a fictive narrative this text seeks to persuade its implied reader to accept its model of female virtue and heroism as appropriate for a young woman of a new nation and a new century.

Stephens' comment on the usual purpose of fiction written for children offers an apt summary of the assumptions and concerns embodied in this text:

... its intention [is] to foster in the child reader [young reader] a positive apperception of some socio-cultural values which it is assumed are shared by author and audience. These values include contemporary morality and ethics, a sense of what is valuable in the culture's past and aspirations about the present and the future.

(Stephens 1992, p.3)

Annie Carr: A Tale of Both Hemispheres frames a model of value from 'the culture's past', retrieved from a period marked by 'the abominable system of transportation' (p.240), and sets up this model of female virtue for emulation by young women some forty years later. The heroine, Annie Carr, is doubly framed by both the narrative voice and a plot which positions her as a powerless, innocent victim. In seeking to represent the past from a more recent perspective the narrative asserts an optimism about the future grounded in the lessons of the past. The text provides a paradigm for considering the narrative strategies which may be employed to position and fix the young female as other and to persuade the reader to accept the constructions of gender, class, family and Australia embodied in the text. 
The Narrator as Authority: Her Story as His-Story

This pseudo-historical retrospective narrative purports to span several decades of colonial history and frames the heroine within the boundaries of a constructed His-story, controlled by a male voice endowed with the status and authority of a medical practitioner. His profession serves to establish his credentials as a scientific, rational man. It is through the construction of this point of view that readers are imperceptibly brought to share the values of the text, because the reader is subject to this perspective for the duration of the narrative and it is assumed that the reader shares the narrator's view of the world.

The narrative is represented as the first person written record of Charles Templeton, who is revealed in the closure to be a very elderly man, recalling events which occurred during the era of convict transportation. Age confers even more authority on his position as omniscient narrator; he is the wise old man who has seen it all, the venerable story-teller of the tribe. As reinforcement of his position as narrative authority Charles is supported by the testimony of another scientific, rational representative of patriarchal wisdom. The details of Annie Carr's past are supplied by her fond uncle/guardian, Dr Grieve, an elderly Scottish doctor whom Charles happens to meet during his studies in Edinburgh. Grieve's account is filtered through Charles's controlling narrative, and contributes to the construction of a reading position which would have been difficult for the implied reader to resist, particularly in its representation of gendered differences.

A reader seeking a detailed representation of colonial life might well be disappointed with Annie Carr. Any sense of the life of the place is limited in this text but underlying assumptions and values can be detected. Charles does mention some place-names in passing,. For example, New Town, some 15 miles from Sydney, is described as a pleasant location for a property; an acquaintance of his has a cottage in Macquarie Street together with a property at Maitland on the Hunter
River; and Sydney Harbour is mentioned as the site for numerous departures and returns. The Templeton home at New Town is set in what seems to be an ordered park, in imitation of English country estates. No native flora or fauna are referred to and the bush is kept safely at bay, fenced off from the orderly life of this colonial family. The indigenous population are notable only by their absence and the convict class, with one exception, are collectively contained elsewhere.

The reader gains an impression of openness and space, of sunlight and warmth. Charles notes with what appears to be approval, his young female cousin's 'sunburnt cheeks' (p.52) and rather rapturously praises 'the clear Australian nights' and 'the resplendent beams of the moon' by which one 'can read [a] book or newspaper almost as easily as in daylight' (p.34)

The negatives of colonial life are represented largely as domestic inconveniences caused by unsuitable servants, and the lack of cultivated aesthetic standards of judgment is lamented:

In those days Sydney was a place where the Arts were not much cultivated. No performers or singers of even fourth or fifth rate European reputation ever found their way to Australia then. There were concerts given of course and singers to be heard at them but they were wretched affairs, as even I who had heard only the drawing-room performances of my own female relatives and their friends could tell.

(p.55)

The assumptions implied by the authoritative voice of the narrator, who presumably possesses an innate critical faculty, are that culture, like manners and morals, must be imported.

A reader with more than a rudimentary knowledge of colonial Sydney might doubt the historical accuracy of a narrative in which specific dates and actual historical personages are conspicuously absent. However, the narrative begins in the colony of New South Wales at a time 'when Melbourne was 
as yet a mere collection of straggling huts with a few stores here and there ... long before gold was thought of' (p.7). As Batman's 'Treaty' with the Port Phillip aborigines was signed in May 1835, the events in this narrative would appear to commence in the late 1830s. While transportation to New South Wales, together with the convict labour assignment system, ceased in 1840, 'there were more convicts in New South Wales at that time than at any other time in history' (Greenwood 1969, p.87). It is significant that in this narrative transportation to New South Wales continues well after 1840 , which lends credibility to Charles's aunt, Mrs Templeton's, 'fear of contamination' (p.26) from contact with the convict population.

Charles tends to regard this fear of the colonial establishment's 'Roman matron' (p.26) as a form of female irrationality:

Her horror of convict contamination was always so great that she would never allow one in the house or near it. She preferred to have free servants - the most insolent, useless wretches they were too - taking all sorts of trouble to train young emigrant girls to domestic service and then paying very high wages to keep them, when she might have got expert smooth civil-spoken pract ised convict domestics for little or no wages at all! But she never would.

(p.192)

Notwithstanding this implied criticism of his aunt's irrational fear, the privileging of feminine purity and innocence over worldly-wisdom and experience, which are perceived as contamination, links with a range of hierarchical meanings implicit in Charles's representations of gender and class. They are implicit too in his attitudes to the old world and the new and to the past and the present.

The young Charles Templeton holds a privileged position in the colony by virtue of his uncle's status as head of the convict department in Sydney. Apparently an orphan brought up by his uncle and aunt, Charles appears to lead a particularly leisured life engaged in private study in preparation for a return to the old world to sit for medical examinations in Edinburgh. Charles has the freedom to travel back and forth from new to old world and within the colony of New South Wales. He is, at the beginning of his narrative, visiting a friend's property near Maitland, on the banks of the Hunter River 'the noblest stream in New South Wales ... a day's steaming north of Sydney' (p.7). In this text the freedom and the means to travel are perceived to be natural male rights accorded to Charles, his cousin Robert, and Dr Grieve, a ship's surgeon by profession. Herbert, a young acquaintance of Charles, has at the beginning of the narrative only recently returned from India bringing with him a bear and a wolf; exotic animals who, after escaping the confines of crude enclosures, roam within his park-like estate. The incompatibility of these animals to either an Indian or an Australian environment is not remarked upon. They are perceived simply as the spoils of a young male traveller.

In contrast, women who travel, particularly young women, are on the whole not to be trusted. The young emigrant girls that his aunt prefers to train as domestic servants rather than accepting assigned convicts are dismissed as mostly insolent, useless wretches'. The eight governesses Mrs Templeton had previously engaged to educate her young daughters, Louisa and Mary, all proved to be unsatisfactory:

... three were so outrageously ignorant that their impudence in assuming the character at all was positively marvellous. Two were very well fitted for the post but unfortunately being good looking, well conducted girls as well, they received offers of marriage from eligible quarters a few months after their engagements... Of the rest two were tolerably well qualified for the post but were found to be frivolous and flighty.

(p.19)

A glance at the descriptors assigned to these young women (my emphases) demonstrates Charles's habit of labelling, classifying and pronouncing judgment 
on females as if they were specimens. The finest specimens are judged on their suitability for a socially approved marriage so enabling the young woman to be claimed by the ranks of establishment order. His greatest disapproval is reserved for the last of the eight governesses, Miss Bellew, who initially is pronounced to be faultless:

My aunt, as weeks passed by and her [the governess's] good qualities developed themselves could not sufficienlly congratulate herself on the possession of such a treasure. She was a most accomplished musicinn, spoke several languages, was a very well informed woman, and had - what so few possess - the gift of conveying her own knowledge to her pupils.

(p.19)

The position of the young isolated female within this hierarchical social order is clearly signified by the phrase, 'the possession of such a treasure'. She is an object which, if considered worthy, is to be possessed, a treasure to be mined. Sadly Miss Bellew is discovered to be not quite worthy of such an honour! She is a thief who pilfers a few paltry articles and is arrested. Charles's patronising comment on this episode categorises the female as duplicitous and non rational: 'it seemed inexplicable that any rational human being should risk soul and body for these paltry items]' (pp.20-1). Miss Bellew's own explanation as to why she might have 'risked body and soul' for such trifles is not recorded. Instead, in entreating pardon she offers the deprivation of maternal influence from infancy as the cause of her transgression. The text is rich in comment on the powerful socializing role assigned to mothers in 'training a young girl in the way she should go' (p.21).

The narrative offers no comment on the virtual enslavement of emigrant governesses, dislocated, employed on meagre salaries and subject to dismissal for any transgression of establishment order. Miss Bellew's sad little story is not offered to evoke sympathy for her position but rather to enforce a particular view of moral rectitude and female weakness. While she is erased from the text immediately, a reader might well recall her story in the later disclosures concerning Annie Carr's troubled childhood and adolescence.

Charles's position in the Templeton family is an ideal one from which to observe, comment and judge. As nephew rather than son, he enjoys all the status and wealth of the family but at a slight distance which is presumably supposed to give his account of events the authority of objectivity. Further, Charles informs the reader that as a young man he was praised for having 'an old head on young shoulders' (p.46) and that he was often the confidant of his aunt in matters familial and domestic. He functions throughout the text as a kind of family watch-dog, keeping everything under surveillance, sniffing out tensions and noting aberrations.

His gaze is most frequently fixed upon young women as he describes, defines and categorizes them. He is most frequently positioned in partial concealment; beside doorways (p.55); gazing through windows (p.64); behind trees and bushes (p.72); and in the shadows (p.34). There is a very strong suggestion of voyeurism in Charles's overseeing and over-hearing but he himself is never subject to critical scrutiny, nor are other males of his class. Given Charles's role as self-appointed scrutineer of moral order, it is ironic but necessary for the initiation of the mystery which drives the plot that he is absent from Sydney when two unusual and intrinsically connected events occur. He is amazed to hear that his cousin Robert Templeton, a little older than he but with whom he has enjoyed a very close relationship, has returned unexpectedly from England where he has been studying, without having informed Charles. Even more amazing is that by the time he hastens by steamer from Maitland he discovers that Robert is already aboard a ship leaving Sydney to return to England.

Particularly frustrating for our watch-dog is that he is unable to discover the reason for this extraordinary behaviour. All he can observe is his aunt's unusual 
lack of composure: she has previously been categorised as 'a stoic Roman matron' (p.26). He has to rely on the report of his young female cousins of an interview between Robert and his parents to which Louisa and Mary attribute the cause of their mother's distress. Being a man, their Papa naturally betrays no emotion.

Recalling the very rigid judgments Charles is in the habit of making on female transgression, his speculation about the kind of 'scrape' Robert might be in demonstrates a revealing double standard:

'Something very wrong, do you mean? I don't think so. He wouldn't oulface his father that way if he had been doing anything he had cause to be ashamed of. I know him better than that. Extravagant he may have been, have got into heavy debt, perhaps killed somebody lfor duelling had not then ceased] got into some scrape or other which he could not well get out of by simply writing home for help and required that he should himself come and see his father to obtain relief. Something it may be of that nature perhaps but anything dishonourable or wicked in the common acceptation of the term I don't believe my cousin would be guilty of.' (pp.28-9)

Charles does not regard a young gentleman's extravagance, heavy debt or even the killing of another in a duel as major transgressions of moral order. They are for him 'scrapes', easily remedied through wealth and influence, most particularly through patriarchal power. The implication is that young gentlemen deserve to be judged more leniently than young governesses.

The second event which without Charles's knowledge is linked to the first, is the arrival of a new governess. For Charles this is particularly unexpected because his aunt had resolved after her experiences with 'unsatisfactory governesses' to undertake the education of her daughters herself. Disturbingly for him, neither his aunt nor unde take him into their confidence and Charles is therefore ignorant of Miss
Carr's background or how or why she came to the colony.

Charles sets himself the task of discovering the mystery of Annie Carr who, unbeknown to him, is his cousin Robert's beloved. Given his characteristic disposition towards surveillance, it is not surprising that she becomes the constant object of his gaze. Reading against the grain discloses not observation but spying; not accidental overhearing but eavesdropping; not natural curiosity but a prurient obsession with the female as other.

When Annie Carr arrives in the Templeton home (the significance of the family name should not go unremarked: temple as edifice dedicated to the service of god) as the new governess she shows signs of 'great strain or tension of the mental faculties' (p.30). In noting this, Charles the rational, the scientific, aligns the female with the irrational, the unstable, the hysteric. Through observing her closely Charles scientifically deduces her character from her physical appearance, a practice he is much in the habit of employing.

While the text is rich with examples of Annie Carr fixed as other by Charles, the following passage yields much through analysis:

Even in perfect health she would not be what anyone would call a beauty. But there was that in it which is so much more pleasing - to me at least - than any mere regularity of feature or brilliancy of colouring that look of feminine softness and tenderness which is so truly attractive. Marred as it was by the hollowness of the eye, the wanness of the cheek and an unmistakable sadness, this expression of gentleness and candour was the predominant characteristic of her aspect. It seemed to me that when in health and strength it would be a most womanly lovable face: one of those which seem expressly formed to be the central sun of some domestic system, to radiate all those influences which make a happy home an earthly heaven.

The beauty which beams from such a countenance is that of a gentle truthful loving spirit - I thought as I 
studied the features of the new governess that they belonged to a true woman and that the soul which lighted them up was untainted by falsity or littleness. Neither so far as I could judge was there any sign of weakness.

(p.30-1)

What the twentieth century reader de tects here is the extremely patronizing tone in which Charles's judgment is offered. She is 'not what one could call a beauty' but this is perceived by the narrator to be a positive, necessary to the construction of 'a true woman'. Charles constructs Annie Carr as unthreatening to the male: 'soft', 'tender', 'gentle', 'loving', 'feminine' and 'untainted'. She is made for submission and male domination, appropriate to be framed as the 'central sun in some domestic system'.

Annie Carr as mythicised 'true woman' functions as other and it is against this otherness that Charles is able to construct a sense of his own identity as masculine. In commenting on the binary oppositions which underpin traditional gender categories Morris observes:

... what is other does not have identity in its own right, it often acts as an empty space to be ascribed whatever meanings the dominant group chooses. Thus women are frail not strong, emotional not rational, yielding not virile so that masculinity can be defined as those positive qualities .... by seeing women as other to themselves, men can read into femininity whatever qualities are needed to construct the masculine. So a mythical 'woman' becomes the imaginary location of male dreams, idealisations and fears.

(Morris 1993, p.14)

The very fact that Annie's physical appearance is neither showy nor sexually aljuring enables Charles to inscribe her as 'true woman'. She offers no threat to his need to believe that sexual activity and dominance are the natural attributes of the male.

Later episodes confirm his fear of overt female sexuality, when he is confronted with women of a different type, but one minor incident in his early acquaintance with Annie Carr is particularly telling. With the excuse of killing a snake, Charles is able to enter Annie's bedroom when she is absent. He discovers a cabin trunk inscribed with her name and the name of the ship which brought her to the colony. He knows it to be a ship used for the transportation of convicts. The inscription on her trunk marks her as convict and therefore more likely to be free with her sexual favours: impure, tainted, a site of contamination. Such a close alignment of two Freudian-charged signifiers - trunk and snake disclose'a subtext of what cannot or dare not be said, of which the writer may not be aware.' (Morris 1993, p.16).

The killing of the snake can well be read then as disclosing the writer's unconscious fear of the female as sexual being, a fear which is projected onto the constructed male authority, Charles Templeton. Such a reading foregrounds an unconscious anxiety about the female as unknowable and duplicitous and the male practice of categorisation represents a defence against this anxiety. Further, Charles's killing of the snake may be read as disclosing an anxiety about sexual temptation, even perhaps as a symbolic act of personal mutilation, in an effort to renounce desire completely. Significantly, Charles never marries nor does he report anywhere in the text on any romantic flirtation or dalliance on his part. His role as moral prefect excludes such fleshly pleasures.

Significantly too, even after Annie's innocence is proved and she is accepted within the establishment family as a fitting wife for the eldest son Robert, the narrator does not mention children born of this union. The text denies Annie the dominant, active and secure role that reproduction and maternity allow women and becomes rather the Templeton's 'Temple', an instrument of divine authority. The privileging of the narrative of the rational male can thus be seen to mask a range of insecurities and anxieties on the author's part, pertaining particularly to sexuality and power. 
The Great Frame-up: Writing a Colonial Cinderella Given the privileging of the point of view of the scientific, rational male as narrative authority it is hardly surprising that the plot of Annie Carr is shaped to conform to the prevailing nineteenth century beliefs in an ordered universe determined by natural and divine laws. The heroine is entangled in a complicated web of deception and intrigue, framed, or so the reader is asked to believe, by the actions of duplicitous and immoral women. Unravelling these entanglements is the task of the active, mobile, scientifically expert male. Annie's task is to sit it out, submissive, chaste and powerless, described at different times by Charles, Dr Grieve and Robert as 'a prize'.

Like the reading position constructed in this text, conservative ideologies are encoded too in the pattern of the plot. Through drawing on the motifs and structural patterning of traditional fairytale, the writer cons tructs a bourgeois fairytale complete with virtuous maiden tested through suffering, a cruel stepmother; a selfish stepsister; a Prince Charming whose kingdom is elsewhere and even a benign godfather who is able to work magic with money and authority at a crucial moment in the plot. Reading Annie Carr as a Cinderella variant makes Jackson's observations on the power of fairytales in confirming and supporting conservative ideologies of gender and power particularly pertinent to this text:

Structurally, too, fairytales discourage belief in the importance or effectiveness of action for their narratives are 'closed'. Things 'happen', 'are done to' protagonists, told to the reader, from a position of omniscience and authority, making the reader unquestioningly passive. (Jackson 1981, p.154)

As Dr Grieve's niece, Annie's position as member of a respectable, moderately affluent, middle-class Edinburgh family is secure, which of course is important for her later acceptance as wife of a Templeton. Having the misfortune tolose her mother in infancy the child is doubly blighted when her feckless father remarries. The second Mrs Carr embodies all the scheming, harshness and envy one would expect to find in the stereotypical fairytale stepmother. When her father subsequently dies, Annie is left in the care of this stepmother. Dr Grieve's description of this unworthy specimen of womanhood makes much of her showiness, vulgarity, artificiality and world liness as signifiers of poor breeding and lax upbringing:

She was proud, vain and thoroughly worldly-minded. Love of display was her great foible. She was wedded to the artificialities of life. She had an income which would have enabled her to live comfortably in a small house: but she preferred a grand house and had people to share it with her. Not that she would have called it a boarding-house though it was in fact nothing else. Being fond of company - 'good society', as she termed it - she arranged with a number of society people to join her in defraying the expenses of a large house, instead of living in a 'dog-hole' or a 'pig sty' as she called all houses of moderate dimensions. There were plenty of plate and show, liveried servants, all the mockery of people aping 'high life' in the house, but very little real comfort.

(p.153)

Dr Grieve's moral disapproval is so strong that 'boarding house' may well be read as a euphemism for bawdy-house. The reader can detect too, moral censure for those who without the right breeding aspire to a higher social position. Significantly he hastens to assure Charles that until the age of eleven Annie had frequently stayed with him and his wife. It is to the maternal affection and influence of that virtuous woman that he attributes the beautiful Christian character which Annie afterwards developed and ... I am convinced that it was Annie's faith and hope in God in her great trouble which saved her from insanity' (p.153). The reader's sympathy for the luckless, motherless Miss Bellew might well be rekindled. There but for the grace of Mrs Grieve might go Annie Carr!

Annie's troubles are increased when the impeccable mother substitute dies. Thereafter she is in the power 
of the urloving, spiteful stepmother and her equally 'showy', selfish stepsister Edith, whose deficiencies are attributed to bad mothering. Annie is deprived even of the constant surveillance of the uncle patriarch whose occupation as ship's surgeon requires him to be absent for lengthy periods. It is he who has to take up her cause when on return from one of his numerous voyages he finds that'she has been gradually transformed into a complete household drudge' (p.154). She is indeed a Cindermaid whose own protests against these injustices are never represented.

A belief, or at the very least a suspicion, of instability or mental weakness in the female is confirmed in specific ways by Dr Grieve's account of Annie Carr's early life, supporting of course Charles's own conclusions drawn from his phrenological study of the 'objectified' subject at a later time. He explains for example, that on one of his returns to Edinburgh he was struck by her unnatural reserve with him, quite unlike her usual demonstrations of affection and openness:

I thought it was only some hysterical whimsy the child had got into her head. At that critical age (she was then about sixieen) girls get so many 'maggots' as the Scotch call them, in their little skulls: they're hardly responsible beings sometimes. I was glad, though, to think her heart was sound still. I fear she had taken a turn for the worse and that those folk in the big house had spoiled her.

(p.159)

The terms in which his fears for Annie are represented inscribe the young female (about the same age as the implied ideal reader of this text) as hardly rational, mentally lacking, a prey to hysterical whimsy and easily spoilt by a worldly environment. There is no suggestion that young males may be prey to these same weaknesses and yet the representation of the colonial Prince Charming, Robert Templeton, suggests qualities of weakness, selfishness and irresponsibility, particularly in his relationships with women which tend to be ignored or excused as a young man's folly. The assumption is that young men are naturally susceptible to the allures of sexually tempting women. It is such women who require moral censure and punishment, not the men who use them.

Dr Grieve discovers that Annie's genuine, daughterly love for him has been mocked by her stepmother with the insinuation that her displays of affection were motivated by mercenary greed. Burdened by physical ugliness, the doctor's own deception of the young girl is perceived to be an understandable defence against the possibility of female hypocrisy. He allows her to believe that he has lost his fortune; in part to test her genuine affection for him and in part to deter fortune hunters. The effect however, is to frame the gullible heroine in a web of complicated deceits which eventually lead to her conviction and transportation.

It is the good doctor who fixes on Robert Templeton as a suitable match for Annie; it also provides an appropriate way of removing her from the unwholesome environment of her stepmother's house. While unstated, Robert's main claim seems to rest on his connection with Australia, a site preferred for its climate and opportunity for advancement.

Robert's personal worthiness might well be called into question by the reader who is prepared to resist the judgments of male authority. He is at first captivated by Annie's 'beautiful ... showy, ... blackeyed, black-haired, sprightly, rather forward' (p.72) stepsister, Edith. Only after she rejects him in favour of a wealthier man does he turn his attention to Annie. But while the young couple form an attachment, Robert does not formally declare himself. His reasons are not clear but suggest a fear of commitment, perhaps a desire for a more exciting sexual partner. It is rather surprising to read the terms of Dr Grieve's approval of Robert: 'I never knew a young man more prudent and less impulsive.' (p.173) when textual evidence suggests otherwise. He seems a spoilt young man; a creature of impulse, quite willing to exploit situations for his own advantage. 
Alas! Cruel fate conspires to dislocate the heroine at a time when both uncle and her suitor are absent. Her stepmother dies of a paralytic stroke when she learns of the loss of all her property and Annie is forced to take a position as a governess. Divine justice works against the heroine, but ultimately the reader is assured that each bitter blow of fate is all but part of the divine plan.

The reader might well be tempted to fill the gap of Robert's absence with scenes of sexual dalliance for when he returns and seeks Annie out he engages in a prolonged flirtation with one of the ladies of the house where Annie is employed. He persuades the gullible Annie to accept this ploy as a camouflage for having access to her but he is loath to announce their betrothal formally. While Annie is apparently unhappy with his plan, the evasion, deceit and manipulation of this colonial Prince Charming frame her in a nightmare of wrongful conviction and transportation.

The text would have the reader believe that the jilted woman in whom Robert pretended to be interested is the real villain of the piece. It is she, motivated by jealousy, who plants some items of jewellery in Annie's trunk which leads to her arrest and conviction. The lady of blighted hopes is painted as a virago by her erstwhile lover:

I remember her strange demeanour when I parted from her-the paleness of her cheek, the rage in her eyes and the compressed lips which could not open to reply to the farewell 1 uttered. I was told she was a vain, hearlless fool, conceited and silly and I amused myself with her. I am awf ully punished! I might have remembered that such characters are often the most cruel and revengeful when their vanity is wounded. (p.203)

If the lady had been permitted to speak, Robert himself might be have been perceived to be vain, heartless, conceited and silly.

Reading against these male assumptions enables the reader to see this woman who later becomes Mrs
Dawson as equally a victim of Robert's manipulation. The great frame-up of the text is thoughtlessly set in place by the young man who has the approval of those two male authorities - Charles and Dr Grieve.

A male authored plot and a male executed frame-up conspire to produce a representation of the female as either powerless, pure and gullible or active, sexual and knowing. The latter category deserves only punishment and Mrs Dawson, after years of guiltridden anxiety, is dispatched at the hands of her definitely lower-class husband. Her fate is mitigated only by the opportunity for death-bed repentance and a request for forgiveness from the wronged heroine who is meanwhile still serving out her sentence as assigned convict, the model governess of the Templetons.

Mrs Dawson's fate is perceived as fitting, affirming the pattern of divine and natural order: she is cast as a grasping temptress; her end is wretched. Robert Templeton's fate too, affirms assumptions of natural order. He is permitted toindulge in some excesses of remorse and to gain the approval of his establishment parents for marriage to the hapless Miss Carr after seven long years of servitude and scrutiny have judged her to be uncontaminated. $\mathrm{He}$ is redeemed through the example of a 'true woman' and lives on to become an esteemed and godly member of the colonial establishment.

One major difficulty which confronted the author of this text is the problem of writing a 'pure' convict heroine, one worthy of becoming the Templeton's 'Temple' to divine order. Along with the freedom accorded to males to travel and to mix with a range of characters drawn from different rungs of the social hierarchy is the use of illness and injury as devices to account for male absence at crucial moments in the plot. These moments are, of course, the particular times when the heroine is in most need of male power and protection. Significantly, male illnesses are represented as physical maladies whereas the previously noted alignment of the female with the irrational manifests itself in mental 
derangement and regression to childhood. After her arrest, Annie suffers some kind of brain storm which causes amnesia. The voice which is rarely heard is effectively silenced and she can offer no help in her defence. Dr Grieve explains her condition as:

... a state into which she has been hurled by the shock was a very uncommon form of mental observation and consisted not in disorder of the intellectual powers, but in a suspension of them - owing to the complete loss of the memory. She is rendered childlike ... it is a mental derangement likely to last for years perhaps even all her life.

(p.200)

It is indeed a fortunate illness as it allows Dr Grieve to use his position as ship's surgeon to secure employment on the ship which is to transport Annie to Australia. He manages to keep her isolated in the hospital for the entire voyage, safely confined from demoralising contact with the other female convicts. Contamination clearly signifies moral depravity, its source being sexual knowledge, sexual appetite and sexual experience. It is women, not men, who are the source of contamination; Dr Grieve's description makes apparent his own sense of threat:

The convicts on board were, as a whole the vilest lot I ever had to deal with, and I had a constant battle to preserve anything like order. Several times a hundred abandoned creatures were yelling and hooting at me because I had them confined in their berihs to prevent them reaching the decks at night-time. A convict-ship, especially when the freight consisted of women was usually a hell. I know not how to describe it.

Of course I took care that Annie never came into contact with these demoralised women: but she could not help hearing the disturbances which frequently occurred. (p.210)

These women are hardly human; they are collectively 'the vilest lot', 'abandoned creatures', 'a freight from hell'. The implication is that confining them below decks at night is necessary as a protection for the sailors; men defenceless against these hordes of sexually rampant females. The effect on Annie of hearing these disturbances passes unremarked.

It is fortunate too for Annie that she recovers her faculties on the voyage. Given the Templetons' prejudice against the convict class and the pledge they extract that she and Robert have no contact until they are satisfied that she is pure and uncontaminated, extreme manifestations of derangement would certainly have excluded her from acceptance as a daughter-in-law. Inscribed as simple, trusting and forgiving, the embodiment of the eternal child, Annie is admirably equipped for establishment approval.

Annie's task for almost the entire narrative is to convince the Templetons of her virtue; most particularly the matriarch of domestic order whose fear of contamination has been so extreme. She has been accepted reluctantly into their home as the ninth governess and first assigned convict to enter their portals only after Robert's special pleading, which was the undisclosed reason for his unexpected arrival in the early stages of the narrative. Yet, even after something like seven years of impeccable virtue, only the unfortunate Mrs Dawson's deathbed repentance, brought post-haste by the indefatigable Doctor Grieve, leads the Templetons to experience qualms of self-condemnation:

But now they owned with sorrow that an unjustifiable pride had been responsible for their treatment of Annie. It was unjust ifiable because, to any unprejudiced person the taint of the convict-ship was obviously irreconcilable with the goodness, purity and Christian life which the girl had exhibited ever since she entered [their] home. (p.238)

For our heroine to have at the very least expressed some scorn or bitterness for the Templeton's unjustified and paranoid bias would have been refreshing, but there is no such outburst.

The Dark Night of the Soul

Only once is Annie's bitterness and anger registered 
in the text. Notlong after her arrivalin the Templeton's home Charles, eavesdropping again, witnesses her giving way to 'a paroxysm of grief and despair' and even a momentary 'railing against God' (p.33-4). He notes 'a hard, defiant look' which is to his relief soon replaced by one 'relatively calm and subdued' (p.38). That this episode takes place in a concealed corner of the garden at midnight, when she believes herself to be alone, suggests much of her repressed anger and the force of social conditioning which prevents her from speaking in her own voice by daylight, to representatives of the social order who have so constrained her.

Annie's 'dark night of the soul' draws on the conventions of nineteenth century novels which represented female heroism as noble resignation. The aptness of Morris's description of the plots of such novels places Annie Carr clearly within an accepted tradition:

To be heroic, plots tell us, men must embrace action, seeking to shape circumstances to their will, whereas for women heroism consists of accepting restrictions and disappointments with stoicism.

(Morris 1993, p.32)

This episode reinforces too, the inescapable gaze of omniscient male authority which is privileged to see all. Annie's framing as 'true woman' denies her the opportunity to be a real woman.

A potheosis of the Heroine

Annie Carr's final integration with patriarchal order is naturally celebrated through marriage. The description of the ceremony however, carries with it an implied criticism of the old order represented by her parents in law - the Head of the Convict Department and 'the stoic Roman matron' fearful of contamination. Annie includes as her attendants in the bridal party two girls about ten years' old, the daughters of deceased female convicts. These little girls can be read as models for the future: the contaminating influence of their convict mothers will, it is implied, be erased through the example of the heroine who oversees their welfare and education. Her action is perceived to be unsettling to the colonial establishment, 'creating surprise and some little constemation among the good folks of the colony' (p.239), but noted approvingly by the narrator as signalling a new phase in the civilising of the colony, 'finally redounding in their estimation to the bride's credit' (p.239).

Those long years of suffering and patient submission are accepted by Annie as part of a divine plan; shaping and refining her to shape and refine other young colonial women. Working in a confined sphere, Annie's divine mission is both protected and supported by the embodiments of patriarchy, Mr Templeton, Robert, Dr Grieve and even our narrator, Charles. The last pages of this novel inscribe Annie as colonial model. Using her father-in-law's authority, a fortunate legacy from a female admirer in the old world and her own 'true womanhood', she embarks upon a task of colonising female convicts, 'restoring womanhood' and preparing them on the termination of their sentences for 'respectability' and 'honourable vocations' (p.240). The colonised has become the coloniser.

The position of our narrator in the final pages enables the author to create a distance between the events of the past and to look towards a future free of the contamination associated with convictism. While long dead, Annie Carr's influence lives on in the generation of redeemed women whose 'respectable' and 'honourable' lives conform to her pattern of colonial womanhood. It is to them, the reader must assume, that the task of uncontaminated reproduction must fall.

\section{A Tale of Both Hemispheres}

In constructing his text as remembered history, the author endeavours to confront the taint of convictism which blighted the reputation of the developing colony on the verge of nationhood. The text asserts a confidence in rational progress with Australia as the preferred site. Significantly, Britain is perceived as not only the vile source of convictism but as a closed 
system dominated by the aristocracy, consequently offering no opportunity for the advancement of the ambitious, expanding, middle-class. While a certain cultural cringe can still be detected - young men are sent 'home' for education and colonial culture is still measured by imperial standards - Australia is wide open. Significantly the most glowing praise for Australia is accorded by the Edinburgh surgeon, Dr Grieve, who has cast off the bonds of the old world through his numerous sea voyages, some of which have taken him to the new colony.

It was a daydream of the future. I was thinking here how well the Australian climate agreed with me and how little objection I should have to go with Annie to Sydney when she accompanied her husband there; for naturally Robert would like to live near his father and friends, I would not be so selfish as to insist on his staying in England. I had made very many friends in Australia, and had no doubt that I could if I chose to try for it, manage to obtain some official post there. Not that I required it. It would be only to occupy a portion of my time, while I devoted the rest to my favourite physiological studies, for which the Australian seas and shores presented such admirable and as yet almost unworked fields. There was too a great political future before that country, I believed: and my Annie's children might in future years play no little part in helping to lay its foundations.

(p.188)

There are many complacent assumptions here about Australia as a site for male advancement and exploitation; 'an unworked field for study'; a place where a not too arduous 'official post might be obtained' through the right connections; a site for a great political future. Like the female, the place itself offers opportunity for categorisation, appropriation, exploitation and the exercise of power. Significant too are patriarchal assumptions of male rights and privileges; Annie will submissively accompany her husband who would naturally like to live near his father; Annie is expected to produce a dynastic order whose right to power and authority is naturally assumed.
Textual silence on Annie's progeny may be an oversight, but on the other hand, her zealous missionary work in colonising young, powerless females may be read as a compensation for that lack.

The gender model in Annie Carr owes much to what Grimshaw describes as the urban middle class romantic elaboration of the separate spheres appropriate to men and women' (Grimshaw, Lake, McGrath, Quartly 1994, p.117), which formed the basis of the gendered cultural tradition underpinning notions of national identity emerging in the $1890 \mathrm{~s}$. It was argued that so long as men and women kept to their allotted spheres, domestic, social, even national harmony could be maintained. The effect of espousing 'a natural distinction' between the sexes based on 'natural' qualities of masculinity and femininity was not to promote equality but rather to subordinate the female through privileging the physically active public role accorded to the male:

Traditionalists portrayed men as the active sex, defenders of the home, those who fought the public battle for the family and were potentially roughened by it. Women, in contrast were the keepers of the home, the guardian of the family's moral and spirit ual values, and so long as they kept to their allotted sphere, the consciences of men.

(Grimshaw et al. 1994, p.117)

Written as it is to an emerging, conservativelyoriented middle-class, it is hardly surprising that Annie Carr: A Tale of Both Hemispheres supports and confirms such an ideology. In writing the heroine as 'true woman' the author safely consigns Annie Carr to the bounded site of woman's sphere.

In identifying the conservative and restrictive gender representations of this text, it is tempting to adopt a patronising and dismissive position. It may be salutary then to consider the extent to which such ideologies still prevail in our own culture: salutary too, to examine the representations of gender currently encoded in fictions written to the young reader. The author of Annie Carr: A Tale of Both Hemispheres does not eschew a statement of didactic 
intentions which are to provide: 'not diversion only but help, encouragement and warning' (p.245). A hundred years later positioned at the beginning of a new century and very possibly a new concept of Australia as republic, ideologies of gender, class and power maybe less overtly stated but are nonetheless encoded in the very'mode of being' (Stephens 1992, p.12) of narrative fiction.

\section{References}

Annie Carr: A Tale of Both Hemispheres. London, The Religious Tract Society.

Greenwood, Gordon (ed) (1969) Australia: A Social and Political History. Sydney, Angus and Robertson.

Grimshaw, Patricia (1994) 'Man's space, woman's place', in P. Grimshaw, M. Lake, A. McGrath and M. Quartly (eds.) Creating a Nation: 1788-1990. Melbourne, McPhee Gribble, 107-130.

Jackson, Rosemary (1981) Fantasy: The Literature of Subversion. New York, Methuen.

Morris, Pam (1993) Literature and Feminism. Oxford, Blackwell.

Muir, Marcie (1992) Australian Children's Books: A Bibliography Volume One 1774-1972. Melbourne, Melbourne University Press.

Stephens, John (1992) Language and Ideology in Children's Fiction. New York, Longman.

\section{$\rightarrow 20$ :EK}

Biographical Note

Elizabeth Strain is a lecturer in Literary studies at Deakin University. Her primary research interests are nineteenth century representations of child hood and contemporary fiction for adolescents.

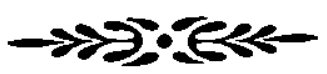

